\title{
A végpontosság mint szituációs aspektuális jegy jelölése a magyar nyelvben. 1. rész
}

1. Bevezetés. Jelen tanulmányunkban azt kívánjuk áttekinteni, hogy a magyar nyelv milyen fö jelölő elemeket használ a végpontosság mint szituációs aspektuális jegy kódolására. ${ }^{1}$ Célunk, hogy a magyar és a nemzetközi szakirodalom legfrissebb eredményeire támaszkodva megmutassuk, hogy az igei predikátumok végpontos (más néven telikus) értelmezése elsősorban 1. eseménymaximalizációs operátort lexikalizáló igekötők és eredményhatározós predikátumok jelenlétében; 2. az egyet, (egy) jót, jókat, (egy) nagyot, nagyokat, hatalmasat stb. áltárgyak révén; és 3. az elfogyasztást és létrehozást kifejező predikátumok kvantált tárgyi argumentuma által válik elérhetővé.

KARDOS $(2012,2016)$ munkája révén demonstráljuk, hogy az igekötők és az eredményhatározós predikátumok egy olyan aspektuális operátort lexikalizálnak, amely az igei predikátum denotációjában lévő esemény legnagyobb, azaz maximális részét ragadja ki. Másrészt, az egyet, (egy) jót, jókat, (egy) nagyot, nagyokat, hatalmasat $\mathrm{stb}$. áltárgyak, amelyek mindezidáig kevesebb figyelmet kaptak az irodalomban, elemzésünk szerint egy olyan operátort kódolnak, amely egy kontextuálisan meghatározott, nem maximális alrészét veszi ki a predikátum denotációjában lévő eseménynek. Végül, az elfogyasztást és létrehozást kifejező igék tárgyi argumentumának esetében megmutatjuk, hogy a telikusság nem jár szükségszerüen együtt eseménymaximalizációval, tehát maximalizáció hiányában is elérhetővé válhat ez az értelmezés.

Jelen tanulmány főként az áltárgyas szerkezetek jellemzésével, valamint az igekötőkhöz vagy eredményhatározós predikátumokhoz, illetve az elfogyasztást és létrehozást kifejező predikátumok kvantált tárgyi argumentumaihoz füzött ki-

${ }^{*}$ Ez a tanulmány nem jöhetett volna létre a Domus Hungarica Scientiarum et Artium támogatása nélkül, amelyet a Magyar Tudományos Akadémia nyújtott Farkas Imola-Ágnesnek. Külön köszönet illeti Kiefer Ferencet, É. Kiss Katalint, Marcel DEN DiKKEnt, BENDE-FARKAS Ágnest, HaLm TAMÁSt, DÉKÁNY ÉVÁt, HEGEDŰS VERONIKÁt és EGEDI BARBARÁt az MTA Nyelvtudományi Intézetében eltöltött idő alatt nyújtott szakmai beszélgetésekért. Ugyanakkor köszönet illeti KÁDÁR EDITet a konzulensi támogatásért és a tanácsokért, valamint azon anyanyelvi beszélőket, akik kitöltötték a grammatikalitási tesztjeinket, és így hozzájárultak a mondataink megítéléséhez. Az itt bemutatott elemzés egy korábbi változatát a berlini Humboldt Egyetemen szervezett Endpoints, scales, and results in the decomposition of verbal predicates címü mühelykonferencián (2018. január 30-31.) mutattuk be.

${ }^{1}$ SMITH (1991) terminológiáját használva szituációs aspektusnak nevezzük az eseménytipológia azon szegmensét, amely az eseménytípusokat állapotokra, cselekvésekre, teljesítményekre, szemelfaktívokra, illetve eredményekre osztja a következő, jól meghatározott szituációs jegyek mentén felvett értékek szerint: statikus/dinamikus, duratív/pillanatnyi, illetve telikus/atelikus. Eszerint például az állapotokat a következőképpen lehetne illusztrálni: [+statikus], [+duratív] és [-telikus]. Az említett jegyek közül a tanulmány középpontjába a telicitás jelölésével kapcsolatos kérdéseket állítjuk.

Magyar Nyelv 115. 2019: 176-185. DOI: 10.18349/MagyarNyelv.2019.2.176 
egészítésével kíván átfogóbb képet nyújtani a magyar nyelv telicitásjelölési módjairól. Fontos célunk, hogy megfogalmazzunk néhány új általánosítást a telikusság megjelenéséről a magyarban azáltal, hogy egy olyan generatív-szemantikai, skaláris keretbe helyezzük elemzésünket, amelyet az utóbbi években számos nyelv eseményszerkezeti jelenségeinek leírására használtak a szakirodalomban. A legfontosabb következtetésünk szerint a magyar nyelv legalább három, egymástól szignifikánsan különböző telikussági jelölési elemet használ, így ebben a nyelvben a telikus predikátumok osztálya egyértelmüen heterogén. E tekintetben a magyar eltér az angol, német és holland nyelvektől, melyek alapvetően az ige belső argumentumának kvantáltsága révén jelölik a végpontosságot (VERKUYL 1972, 1993; TENNY 1994; KRIFKA 1998).

A tanulmány felépítése a következő: a második rész (2.) röviden áttekinti a szakirodalomból ismert, jelen tanulmány szempontjából kiemelt fontosságú, főként a három telikusságot jelölő nyelvi elemről szóló munkákat, illetve ez a rész általános bevezetöül is szolgál az elemzésünk elméleti keretének tárgyalásához. A következő három alfejezet (3-5.) részletesen bemutatja, hogy 1. az igekötők, illetve az eredményhatározós vagy rezultatív predikátumok; 2. az egyet, (egy) jót, jókat, (egy) nagyot, nagyokat, hatalmasat stb. áltárgyak; és 3 . az elfogyasztást és létrehozást kifejező igék belső argumentuma milyen módon járul hozzá az igei predikátumok telikus értelmezéséhez. Végezetül, az utolsó rész (6.) összegzi a tanulmányban leírtakat.

2. Szakirodalom és elméleti bevezető. Bár ez a szakasz csupán egy töredékét mutatja be azoknak a munkáknak, amelyek valamiképpen foglalkoznak a fent említett telikusságot kódoló nyelvi elemekkel, mégis elméleti bevezetőként szolgálhat a telikussági jelölés jelenségköréhez a magyarban, mivel az áttekintésben képviselve vannak a fő́bb elméletek. Hangsúlyozandó, hogy az itt tárgyalt munkák inkább nagyon rövid áttekintés, mintsem kritikai elemzés céljából kerülnek bemutatásra.

Az igekötőkkel kapcsolatban a legfontosabb állítás az, hogy másodlagos predikátumok és helyzetbehatárolók, amelyeket a deriváció elején egy ige utáni pozícióban generálunk, és amelyek a predikációs frázis (Predication Phrase, azaz PredP) specifikálójába (É. KISS 2008) vagy akár egy még fentebbi pozícióba, az igeidő frázis (Tense Phrase, azaz TP) specifikálójába (SURÁNYI 2009b) mozognak fel. Ezen jelölők telicizáló hatása a lexikai értelmezésük egyenes következménye (1. még KIEFER-LADÁNYI 2000; É. KISS 2004). Az igekötőkhöz hasonlóan, az eredményhatározós predikátumok minden esetben behatárolják az igei predikátum cselekvését, mivel ezen szerkezetek egyik legkevésbé ellentmondásos szemantikai jellemvonása pontosan az, hogy kizárólag telikus, jól meghatározott végponttal rendelkező konstrukciók (l. TENNY 1994; LEVIN-RAPPAPORT HOVAV 1995; ROTHSTEIN 2004; GOLDBERG-JACKENDOFF 2004; WECHSLER 2005). Az alábbi példák az igekötők és rezultatív predikátumok ezen telicizáló hatását illusztrálják:

(1) a) Béla 10 percig/*10 perc alatt festett egy keritést.

b) Béla 10 perc alatt ${ }^{*} 10$ percig lefestett egy keritést.

c) Béla 10 perc alatt $* 10$ percig pirosra festett egy keritést. 
Az (1a) példa atelikus olvasatot kap, melyet a 10 percig időhatározó elfogadhatósága és a 10 perc alatt időhatározó agrammatikus volta jelez. Ezzel szemben, a le igekötőt tartalmazó ( $1 \mathrm{~b})$ példa és a pirosra rezultatív predikátumot tartalmazó (1c) példa kizárólag telikusan értelmezhetö.

Az áltárgyak szintén kimérő funkcióval rendelkeznek, és így helyzetbehatárolóként müködnek cselekvést vagy mozzanatot kifejező intranzitív igék esetében (1. PIÑÓN 2001; KIEFER 1994, 2006; CSIRMAZ 2008; HALM 2012; FARKAS 2017, FARKAS-KARDOS 2018). Az igekötőkhöz hasonlóan CSIRMAZ (2008: 183) szerint ezen áltárgyak egy ige utáni pozícióból a PredP specifikálójába mozognak fel, amikor megelözik a (mozzanatos) igét. Cselekvések esetében az áltárgy az ige után fordul elő semleges mondatokban. Ezzel szemben FARKAS-KARDOS (2018) azt állítja, hogy ezen áltárgyakat a $v \mathrm{P}$ és a VP közötti aspektuális frázis (AspP) specifikálójában generáljuk. Ami a denotációját illeti, PIÑÓN (2001: 194) amellett érvel, hogy az áltárgy egy $R$ típusú $e$ eseményt módosít, amelynek futási ideje valódi része egy bizonyos $t$, kontextuálisan meghatározott időintervallumnak. Nagyon lényeges, hogy $t$-n belül nem létezik más, $e^{\prime}$ típusú esemény, amely nagyobb, mint $e$, vagy különbözik tőle. E két feltétel biztosítja azt, hogy az áltárgyas események egyértelmüen telikusak. A (2)-es példában az egyet áltárgy mozzanatos igékkel fordul elö, míg a (3)-as példában az egy jót és egy nagyot áltárgyak cselekvést kifejező igékkel fordulnak elő.

(2) a) A beteg egyet köhintett.

b) Géza egyet pislantott.

(3) a) Attila futott egy jót.

b) A fiatalok táncoltak egy nagyot.

Az elfogyasztást és létrehozást kifejező igék belső argumentumát illetően elmondhatjuk, hogy a magyarban a kvantált referenciával rendelkező tárgyak hozzájárulhatnak a telikus interpretációhoz, a kumulatív referenciával rendelkező belső argumentumokkal ellentétben, amelyek - a megfelelö angol szerkezetekhez hasonlóan - atelikus olvasatot eredményeznek (1. VERKUYL 1972; É. KISS 2008; KARDOS 2012, 2016). Az alábbi példákon keresztül hasonlítjuk össze a két nyelv ebbe a csoportba tartozó predikátumait.

(4) a) Sára 10 perc alatt rajzolt egy virágot.

b) Károly 10 perc alatt ivott egy limonádét.

a) Sara drew a flower in 10 minutes.
Sára rajzolt egy virág 10 percen.belül
'Sára 10 perc alatt rajzolt egy virágot.'
b) Charles drank a lemonade in 10 minutes.
Károly ivott egy limonádé 10 percen.belül
'Károly 10 perc alatt ivott egy limonádét.'

A fenti mondatok mindegyikében kvantált théma argumentummal fordul elő az igei predikátum. Ennek megfelelően a magyar egy virág és egy limonádé de- 
notációinak nincsen olyan valódi része, amelyre vonatkozhatnak ezek a kifejezések, hasonlóan az angol a flower és a lemonade fönévi csoportokhoz. Ezen théma argumentumok kvantáltsága telikus olvasatot eredményez a magyar és az angol adatok esetében is, melyet a 10 perc alatt (4), illetve az in 10 minutes időhatározók (5) elfogadhatósága mutat minden példában.

Ezzel szemben nem kvantált/kumulatív jelöletü théma argumentumok esetében kizárólag atelikus olvasatot kapunk a magyar (6) és az angol (7) adatok esetében is:

(6) a) Sára 10 percig/*10 perc alatt virágokat rajzolt.

b) Károly 10 percig/*10 perc alatt limonádét ivott.

(7) a) Sara drew flowers for 10 minutes /*in 10 minutes. Sára rajzolt virágok 10 percig 10 percen.belül 'Sára 10 percig/*10 perc alatt virágokat rajzolt.'

b) Charlesdrank lemonade for 10 minutes $/ *$ in 10 minutes. Károly ivott limonádé 10 percig 10 percen.belül 'Károly 10 percig/*10 perc alatt limonádét ivott.'

A továbbiakban a három telikusságot jelölő elemet egy skaláris szemantikai elméleti keretben tárgyaljuk (1. HAY-KENNEDY-LEVIN 1999; WECHSLER 2005; KENNEDY-LEVIN 2008), melyben feltételezzük, hogy az állapotváltozást kifejező predikátumok lexikalizálnak egy skaláris argumentumot, melynek rész-egész szerkezeti tulajdonságait örökli az igei predikátum által leírt esemény rész-egész szerkezete a köztük fennálló homomorfizmusnak köszönhetően (1. KRIFKA 1998; BEAVERS 2012). FiLIP-RothSTEIN (2006) és FiLIP (2008) alapján a telikusság az igei predikátumok egy bizonyos alosztályának esetében eseménymaximalizáció eredménye, melynek bemenetét részbenrendezett események alkotják, kimenetét pedig maximális események (a predikátum által leírt legnagyobb események LANDMAN [1992] szerint). Az eseménymaximalizáció kötelező érvényủ a magyarban a nem elfogyasztást és létrehozást, hanem állapotváltozást leíró predikátumok osztályában, amennyiben az ige kódol inkrementalitást, valamint a théma argumentum által jelölt résztvevő mennyisége és a skála végpontja ismert (KARDOS 2016).

3. Az igekötő és a rezultatív predikátum. Ebben az alfejezetben amellett fogunk érvelni, hogy a telicizáló igekötők az igei predikátumokat azáltal teszik végpontossá, hogy lexikalizálnak egy e s e én y maximalizációs operá to r t, melyet FILIP-RothSTEIN (2006), FILIP (2008) és KARDOS (2012, 2016) munkái alapján $M A X_{E}$ operátornak nevezünk. Az operátor fontos aspektuális következménye, hogy a magyarban az igekötős kifejezések kvantáltak, tehát szükségszerúen telikusak. Ezt illusztrálják a következő példák:

(8) a) Béla 10 percig/*10 perc alatt festett egy keritést.

b) Béla 10 perc alatt $/ * 10$ percig lefestett egy keritést.

(9) a) Sára 10 percig/*10 perc alatt takaritott egy szobát.

b) Sára 10 perc alatt $/ * 10$ percig kitakaritott egy szobát. 
(10) a) Csaba 10 percig/*10 perc alatt faragott egy fadarabot.

b) Csaba 10 perc alatt $/ * 10$ percig kifaragott egy fadarabot.

A (8)-(10)-es példákban található időhatározók (10 perc alatt és 10 percig) azt jelzik, hogy igekötő hiányában kötelezően atelikus értelmezést kapunk a fest egy keritést, takarit egy szobát és farag egy fadarabot igei predikátumok esetében, még akkor is, ha van egy behatárolt tárgyi argumentum az ige mellett (egy keritést, egy szobát és egy fadarabot), míg a le és ki igekötők jelenlétében kizárólag a telikus értelmezés érhető el.

Ezen adatok azért is érdekesek, mert más nyelvekben, mint például az angolban (1. [11]) vagy a románban (1. [12]), ugyanazon igék esetében (fest, tisztit/takarit), igekötő hiányában is, csupán a behatárolt tárgyak jelenlétében a telikus értelmezés a preferált. ${ }^{2}$ Ez csak olyan igék esetében fordul elő, amelyek által leírt eseményeket a tárgy ki tudja mérni (vö. TENNY 1994; VERKUYL 1993; KRIFKA 1998).
(11) a) Béla
painted a fence
in 10 minutes /??for 10 minutes.
Béla
festett egy kerítés
10 percen.belül 10 percig
'Béla 10 perc alatt lefestett egy kerítést.'
b) Sarah cleaned a room in 10 minutes /??for 10 minutes. Sára tisztítottegy szoba 10 percen.belül 10 percig 'Sára 10 perc alatt kitakarított egy szobát.'
(12) a) Béla a vopsitun gard in 10 minute /??timp de 10 minute. Béla festett egy kerítés 10 percen.belül 10 percig 'Béla 10 perc alatt lefestett egy kerítést.'
b) Sara a curățat o cameră in 10 minute /??timp de 10 minute. Sára tisztított egy szoba 10 percen.belül 10 percig 'Sára 10 perc alatt kitakarított egy szobát.'

Az angol adatokat illetően még azt is fontos megjegyezni, hogy az olyan predikátumok esetében, mint a warm 'melegít', cool 'hüt' és lengthen 'hosszabbít' (fokozati eredményigék, 1. DOWTY 1979: 88-90), aspektuális kétértelmüség figyelhető meg: a predikátum behatárolt tárgy jelenlétében a szövegkörnyezettől függően értelmezhető atelikusan és telikusan is:

(13) a) John warmed a plate for 10 minutes /in 10 minutes. János melegített egy tányér 10 percig 10 percen.belül 'János 10 percig melegített egy tányért /10 perc alatt felmelegített egy tányért.'

b) Ben cooled aglass for 10 minutes /in 10 minutes. Ben hütött egy pohár 10 percig 10 percen.belül 'Ben 10 percig hütött egy poharat /10 perc alatt lehűtött egy poharat.'

${ }^{2}$ Itt jegyeznénk meg, hogy a román nyelvben (és általában a román nyelvekben) nem léteznek igekötők, így igei predikátumokat ezzel a módszerrel nem lehet behatárolni (1. még FARKAS 2013). 
c) The tailor lengthened a skirt for 10 minutes/in 10 minutes. a szabó hosszabbított egy szoknya 10 percig 10 percen.belül 'A szabó 10 percig hosszabbított egy szoknyát/10 perc alatt meghoszszabbított egy szoknyát.'

Bár az elsődleges értelmezés atelikus a fenti példákban (1. HAY-KENNEDYLEVIN 1999: 127), a kontextus elérhetővé teheti a telikus olvasatot is. A (13a)ban található mondat például értelmezhető úgy, hogy egy tányér elért egy kontextuálisan meghatározott hőmérsékletet (tehát készen áll például arra, hogy felszolgáljuk benne az ételt), a (13b) mondat egy pohárról állíthatja azt, hogy elért egy kontextus által specifikált hőmérsékletet, míg a (13c) szerint egy szoknya érhetett el egy valamilyen, kontextus által specifikált hosszúságot.

Hasonló kétértelmüség figyelhető meg az angol wipe a table '(le)töröl egy asztalt', scrub a bathtub '(meg)súrol egy kádat' és sweep the floor '(fel)sepri a padlót' predikátumok esetében is (vö. LEVIN-SELLS 2009: 311).
(14) a) John wiped a table in 10 minutes /for 10 minutes. János törölt egy asztal 10 percen.belül 10 percig 'János 10 perc alatt letörölt egy asztalt /10 percig törölt egy asztalt.'
b) Kate scrubbed a bathtub in 10 minutes /for 10 minutes. Kati súrolt egy kád 10 percen.belül 10 percig 'Kati 10 perc alatt kisúrolt egy kádat /10 percig súrolt egy kádat.'
c) David swept the floor in 10 minutes /for 10 minutes. Dávid seperte a padló 10 percen.belül 10 percig 'Dávid 10 perc alatt felseperte a padlót /10 percig seperte a padlót.'

Míg az elsődleges olvasat mindhárom példa esetében telikus a behatárolt tárgyi argumentumnak köszönhetően, az atelikus értelmezés is elképzelhető bizonyos kontextuális feltételek mellett. Az események akkor kulminálnak, amikor az asztalt teljes terjedelmében letörölte János (14a), a kádat teljes terjedelmében kisúrolta Kati (14b), és a padlót teljes terjedelmében felseperte Dávid (14c). Az atelikus olvasat esetében a predikátum által leírt események többször ismétlődnek; végpont az eseményleírásokhoz nem jelölhető ki.

A magyarban ezekben az esetekben nem megengedett az aspektuális variabilitás; az eseménymaximalizációval ez nem egyeztethető össze (1. még KARDOS 2012: 112, ill. KARDOS 2016: 27 példáit is).

(15) a) János 10 percig/*10 perc alatt melegitett egy tányért.

b) Péter 10 percig/*10 perc alatt hütött egy tányért.

(16) a) János 10 perc alatt $/ * 10$ percig megmelegitett egy tányért.

b) Péter 10 perc alatt $* 10$ percig lehütött egy tányért.

(17) a) János 10 percig/*10 perc alatt törölt egy asztalt.

b) Kati 10 percig/*10 perc alatt súrolt egy fürdőkádat.

c) Sára 10 percig $/ * 10$ perc alatt seperte a padlót. 
(18) a) János 10 perc alatt $/ * 10$ percig letörölt egy asztalt.

b) Kati 10 perc alatt/*10 percig megsúrolt egy fürdökádat.

c) Sára 10 perc alatt $/ * 10$ percig felseperte a padlót.

Míg a (15)-ös példákban a melegítési és hütési eseményleírások nem behatároltak, tehát az igei predikátumok egy melegítési és hütési állapotváltozást fejeznek ki anélkül, hogy megneveznének egy végpontot az eseményhez, a (16)-os példák által kifejezett események szükségszerüen végpontosak. ${ }^{3}$ Hasonlóképpen kötelezően atelikusak a (17)-ben található, igekötő nélkül előforduló predikátumok, míg telikusak a (18)-beli igekötős példák.

Az igekötők által kódolt eseménymaximalizáció fontos következménye még, hogy a théma argumentum által jelölt entitás mennyiségét specifikálni kell ahhoz, hogy grammatikus mondatot kapjunk. Ezt a szemantikai megkötést szemléltetik a (19)-es és a (20)-as példák:

(19) a) *János megmelegitett tányérokat.

b) János megmelegitette a tányérokat.

c) János megmelegitett három tányért.

(20) a) *Kati lehütött poharakat.

b) Kati lehütötte a poharakat.

c) Kati lehütött három poharat.

Amennyiben feltételezzük, hogy a fenti mondatok neutrálisak (tehát nem tartalmaznak például fókuszt), egyértelmüen látható, hogy a megmelegit és lehüt igék környezetében nem fordulhat elő puszta többes számú théma (KIEFER 1992; SZILI 2001; É. KISS 2005, 2008), hiszen az ilyen típusú belső argumentum nem specifikálja az állapotváltozással jellemezhető résztvevő mennyiségét. A határozott névelővel vagy számnévvel előforduló fönevek kvantáltsága viszont, melyet a fentebbi (b) és (c) példák illusztrálnak, eleget tesz a fenti szemantikai megkötésnek.

Érdekes, hogy az angolban előforduló partikulák (mint például az up) nem befolyásolják a tárgyi argumentum referenciális tulajdonságait (BORER 2005) olyan módon, mint ahogy azt a magyar igekötők esetében megfigyelhetjük (KARDOS 2012: 117, 2016: 20). A következő példák ezt illusztrálják:

(21) a) The sous chefs warmed up cups for an hour /*in an hour. a kukták melegítettek fel csészék egy óráig egy órán.belül 'A kukták egy órán keresztül csészéket melegítettek.'

b) The sous chefs warmed up three cups in an hour/*for an hour. a kukták melegítettek fel három csésze egy órán.belül egy óráig 'A kukták egy óra alatt felmelegítettek három csészét.'

A magyar igekötőktől eltérően az angol partikulák előfordulhatnak többes számú théma argumentummal, mely esetben atelikus értelmezést kap a prediká-

${ }^{3} \mathrm{Az}$ angol nyelvủ szakirodalomban fokozati eredményként (degree achievement) ismert predikátumok morfológiai és szemantikai tulajdonságait a magyarban többek között SzILI (2015) tárgyalja. 
tum (21a). Amennyiben specifikáljuk a théma által leírt résztvevő mennyiségét, telikusságot kapunk (21b). BORER (2005: 211) megjegyzi, hogy az anyanyelvi beszélők néha eltérő grammatikalitási ítéletet rendelnek az olyan mondatokhoz, mint a (21a). Bizonyos beszélők számára tökéletesek, míg másoknak kevésbé elfogadhatóak az ilyen példák. A magyar beszélők ezzel szemben egyértelmüen elutasítják a (19a) és a (20a) típusú mondatokat (feltételezve, hogy ezek neutrális mondatok). Ez az eltérés a két nyelvre jellemző grammatikalitási ítéleteket illetően egyértelmü következménye az angol partikulák és a magyar igekötők által kódolt eltérő aspektuális információnak.

Egy további szemantikai megkötés is megállapítható az igekötős ige által kódolt skálával kapcsolatban: a skála végpontja specifikusan megjelölhető kell, hogy legyen, mint ahogy ezt a következő mondatok is mutatják:

(22) a) \#János megmelegitett egy tányér levest, de az nem lett elég meleg. ${ }^{4}$

b) \#Péter lehütött egy pohár sört, de az nem lett elég hideg.

c) \#A munkások kiszélesitettek egy utat, de az nem lett elég széles.

A fenti példákban azért figyelhető meg szemantikai anomália (amit a \# jel mutat), mert a második tagmondat mindhárom esetben tagadja az első tagmondatból következő végpontosságot. A (22a)-ban ez a végpont a leves egy kontextuálisan meghatározható meleg állapotának felel meg, míg a (22b)-ben a sör egy kontextuálisan meghatározható hideg állapotát jelenti. A (22c)-ben egy út kellően széles állapotának elérését tagadjuk le a második tagmondatban, amely azonban nem összeegyeztethető az igekötős kiszélesit egy utat predikátummal az első tagmondatban. Ez az anomália akkor nem áll fenn, ha az első tagmondatban elhagyjuk az igekötőt:

(23) a) János melegitett egy tányér levest, de az nem lett elég meleg.

b) Péter hütött egy pohár sört, de az nem lett elég hideg.

c) A munkások szélesitettek egy utat, de az nem lett elég széles.

Amint azt PIÑóN (2008: 93) is kifejti, az ebben a részben bemutatott igekötős szerkezetek ún. erős teljesítményekként (angolul strong accomplishment) müködnek. Ilyen értelemben ezen konstrukciók esetében:

1. A majdnem határozószó jelenléte kétértelmű mondatot eredményez, amelynek lehet a) té n y elle nes (counterfactual) értelmezése, ahol a határozószó tagadja az esemény elkezdését, így a teljes esemény létezését/létrehozását is, vagy

${ }^{4}$ Amint azt az egyik névtelen bíráló is megjegyzi, a magyar nyelvben az igekötős inchoatívumok értelmezéséből nem lehet kizárni a többféle olvasatot is megengedő pragmatikai aspektust. Eszerint a (22a) mondat például kifejezhet egy, a beszélő által teljesnek mondható állapotváltozást, mégis, az elvárásokkal ellentétben, ez az állapotváltozás nem feltétlenül mondható teljesnek, ezért ez a mondat tagadható: János megmelegitett egy tányér levest, de Annának nem volt elég meleg. Más szóval, ezen mondatok a pragmatikai aspektus alkalmazásának szükségessége mellett szólnak. A bíráló szerint a megmelegített egy tányér levest szerkezet inkább a 'létrehozás' jelentést fedi le (létrehozott egy tányér meleg levest), így az igazi anomáliát e ténynek a tagadása jelentené: \#Megmelegitett egy tányér levest, de nem lett egy tányér meleg leves. 
b) skaláris (scalar) olvasata, ahol a határozószó tagadja az esemény befejezését, amint azt a (24a)-beli mondat által előidézett értelmezések is mutatják. Ez alátámasztja azt a hipotézist, miszerint ezen konstrukciók komplex, azaz összetett eseményszerkezettel rendelkeznek.

2. Amint azt fentebb is láttuk a (19a)-ban és a (20a)-ban, az ige utáni tárgy pozícióját nem foglalhatja el egy puszta, többes számú főnév (1. [24b]).

3. Az igekötős konstrukció magába kódolja a befejezés azon részét, illetve a befejez ige értelmezésének azon komponensét, amely megakadályozza, hogy ezen szerkezetek által kifejezett cselekvés folytatható vagy megismételhetö legyen. Ezekben az esetekben az igekötő által kifejezett végpont elérésekor valamilyen állapotváltozás történik vagy utána a cselekvés megszünik (1. [24c] és [24d]).

(24) a) Béla majdnem lefestett egy keritést.

(tényellenes értelmezés: 'Kati el sem kezdte a cselekvést'.)

(skaláris értelmezés: 'Kati elkezdte, de nem fejezte be a cselekvést'.)

b) *János megmelegitett tányérokat.

c) \#Kati kisúrolt egy fürdőkádat, aztán később megint kisúrolta azt.

d) Sára reggel kilenc órakor elkezdte kitakaritani a szobát, aztán tíz órakor be is fejezte.

Ami a tagadást illeti (1. PIÑÓN 2008: 102-105), mivel az erős teljesítmények preszuppozíciósak, a bennük kódolt két preszuppozíció megmarad a tagadás esetén is, és így újra kétértelmü mondatot kapunk:

(25) Béla nem festett le egy keritést sem.

(1. értelmezés: 'Béla el sem kezdte a cselekvést'.)

(2. értelmezés: 'Béla elkezdte, de nem fejezte be a cselekvést'.)

Aspektuális szempontból az igekötős igék ugyanúgy viselkednek, mint a rezultatív kifejezésekkel előforduló igei predikátumok. ${ }^{5}$ Először is, az ilyen eseményleírások kötelezően telikusak:

(26) a) Béla 10 perc alatt/*10 percig pirosra festett egy keritést.

b) Kati 10 perc alatt $/ * 10$ percig tisztára súrolt egy kádat.

c) Csaba 10 perc alatt ${ }^{*} 10$ percig díszesre faragott egy fadarabot.

A rezultatívok környezetében sem fordulhat elö olyan théma argumentum, amely nem specifikálja az állapotváltozással leírható résztvevő mennyiségét.

(27) a) *Béla pirosra festett kerítéseket.

b) *Kati tisztára súrolt kádakat.

c) *Csaba díszesre faragott fadarabokat.

${ }^{5}$ Jelen tanulmányban kizárólag azon állapotváltozást kifejező eredményhatározós szerkezetekre fókuszálunk, amelyeket a sublativusi -ra/-re rag jelöl. 
Továbbá, a rezultatív kifejezés pontosan specifikálja a théma argumentum által leírt résztvevő végállapotát:

(28) a) \#Béla pirosra festett egy keritést, de az nem lett piros.

b) \#Kati tisztára súrolt egy kádat, de az nem lett tiszta.

c) \#Csaba díszesre faragott egy fadarabot, de az nem lett díszes.

Amint a fenti példák is mutatják, szemantikai anomáliához vezet a piros, tiszta és díszes végállapotok tagadása a pirosra, tisztára és díszesre rezultatív predikátumok megjelenése esetén az első tagmondatban.

Az igekötők és a rezultatív kifejezések együtt is előfordulhatnak egy eseményleírásban:

(29) a) Béla befestett pirosra egy keritést.

b) Kati kisúrolt tisztára egy kádat.

A (29)-es példákban a két telikus jelölő aspektuálisan azonos funkciót lát el, hiszen mind a be és a ki igekötők, illetve a pirosra és tisztára rezultatív predikátumok is kódolnak egy eseménymaximalizációs operátort; aspektuálisan tehát redundásnak tekinthető az egyik jelölő. Abban a tekintetben viszont különböznek, hogy míg a rezultatív kifejezések minden esetben pontosan megnevezik a théma argumentum által leírt résztvevő végállapotát (a kerítés piros lett a [29a]-ban, a kád pedig tiszta a [29b]-ben), előfordul, hogy az igekötő az eseményhez csak egy végpontot rendel, anélkül, hogy pontosan specifikálná azt. A befest predikátum esetében például csak azt tudhatjuk pontosan, hogy a kerítés teljes terjedelmében be lett festve, azt viszont nem, hogy milyen színüre festették.

Összegezve tehát láthatjuk, hogy az igekötők és rezultatív kifejezések jelenlétében kötelezően telikus olvasatot kapunk a magyarban egy eseménymaximalizációs operátornak köszönhetően, amelynek bemenetéül az igei predikátumok által kifejezett legnagyobb (maximális) események szolgálnak. Ettől valamelyest eltérő aspektusjelölő eszköz figyelhető meg az áltárgyas konstrukciók esetében, melyeket a következő szakaszban tárgyalunk.

(Folytatjuk.)

FARKAS IMOLA-ÁGNES

Babeș-Bolyai Tudományegyetem

KARDOS ÉVA

Debreceni Egyetem 